\title{
RETORIKA DAKWAH YUSUF MANSUR DAN PEMANFAATANNYA SEBAGAI BAHAN AJAR BERBICARA DALAM BENTUK CD INTERAKTIF UNTUK SISWA SMA
}

\author{
Puri Pramita \\ Universitas Pendidikan Indonesia
}

\begin{abstract}
Abstrak
Penelitian ini bertujuan mendeksripsikan retorika dakwah Yusuf Mansur meliputi struktur materi dakwah, metode dakwah, strategi penyusunan pesan, dan gaya dakwah, serta pemanfaatan hasil penelitian sebagai bahan ajar berbicara dalam bentuk CD interaktif untuk siswa SMA. Pendeskripsikan retorika dakwah Yusuf Mansur menggunakan metode deskriptif analisis berdasarkan teori retorika dakwah. Komposisi struktur materi dakwah Yusuf Mansur bagian pembuka ceramah berupa salam pembuka, pujian kepada Allah Swt, shalawat kepada Rasulullah Saw,dan pernyataan pengantar menuju pokok dakwah. Bagian isi dakwah Yusuf Mansur terdiri atas contoh, kisah, dalil Al-Qur'an, dan wasiat. Bagian penutup berupa simpulan, harapan, doa, dorongan untuk berbuat, dan salam penutup. Metode dakwah Yusuf Mansur yakni metode dakwah Al- Mauizah Al- Hasanah berupa kisah, contoh, wasiat, dan pernyataan persuasi. Yusuf Mansur juga berdakwah dengan metode Al-Hikmah berupa pernyataan logis, faktual, dalil sahih dan kebenaran mutlak. Strategi penyusunan pesan dakwah Yusuf Mansur secara keseluruhan berupa imbauan rasional dan emosional. Gaya dakwah Yusuf Mansur dari segi komunikasi termasuk santai dan bersahabat dengan diksi berdialek Betawi dan percakapan sehari-hari. Gaya bahasa yang dominan digunakan gaya bahasa penegasan dan perbandingan. Pola retorika dakwah Yusuf Mansur dijadikan bahan ajar multimedia interaktif dengan mendesain peta konsep, RPP, flowchart, dan storyboard pembelajaran berbicara menggunakan metode tanya jawab, pemodelan, dan latihan.
\end{abstract}

Kata Kunci: Retorika dakwah Yusuf Mansur, bahan ajar, berbicara, CD interaktif.

\begin{abstract}
This research aims to describe the religious proselytizing rhetoric of Yusuf Mansur includes the religious proselytizing's structure, the method, message conveying strategy, religious proselytizing style and its implication as the speaking material in the form of interactive CD for Senior High School Students.. The description of Yusuf Mansur religious proselytizing used descriptive analysis method based on religious proselytizing rhetoric theory. The opening compositions of Yusuf Mansur religious proselytizing includes greeting, approbation toward Allah Almighty, Shalawat toward prophet Muhammad and the introduction toward the core
\end{abstract}


of the religious proselytizing. The content of Yusuf Mansur's religious proselytizing consists of sample, hope, prayer, suggestion and closing remark. The method which is commonly used in Yusuf Mansur's religious proselytizing is Al-Manizah Al- Hasanah method which gives example, admonition and persuasion. Yusuf Mansur also uses Al-Hikmah method which contains logical statement, fact, strong theorem and absolute truth. The strategy of composing the religious proselytizing message as general is a rational appealing and emotional appealing. The style of Yusuf Mansur's religious proselytizing from the side of communication includes the casual one and friendly, mostly the diction used by Yusuf Mansur is diction in Betawi dialect version and daily conversation. The dominant metaphor used is the confirmation and comparison. The pattern of Yusuf Mansur religious proselytizing is utilized into interactive multimedia material by designing the concept map, lesson plan, flowchart and the storyboard for speaking learning using question and answer method, model and exercise.

Key Word: Religious Proselytizing Rhetoric Yusuf Mansur, Material, Speaking, Interactive $C D$.

\section{PENDAHULUAN}

Retorika memegang peranan penting dalam kegiatan berbicara. Hal ini sudah lama disadari para komunikator andal bahkan menurut sejarah, retorika telah berkembang di Yunani sekitar abad ke-5 sebelum Masehi. (Arsjad dan Mukti, 1988, hlm. 3). Kemampuan retorika berperan penting dalam pencapaian tujuan berbicara. Aristoteles (dalam oka 1976, hlm. 8) mengemukakan "Setiap orang memanfaatkan retorik menurut kemampuannya masing-masing, ketika mereka bertutur.". Pertimbangan mengunakan strategi retorika disesuai dengan kondisi dan pribadi pembicara. Umumnya, persiapan berbicara dilaksanakan sesuai dengan tujuan tertentu baik dalam politik, kampanye, iklan, penyampaian nasihat dan dakwah.

Salah satu ragam keterampilan berbicara yang sering dilakukan ialah berdakwah. Berdakwah pada umumnya berorientasi perihal keagamaan atau hal-hal khusus lainnya. Dakwah yang baik mampu memberikan pengaruh pada pendengar. Pengaruh yang diharapkan ialah perubahan sikap dan ajakan sesuai ajaran agama. Kemampuan berdakwah merupakan keterampilan berbicara yang harus dimiliki sedini mungkin (Muhtadi, 2012, hlm. 4). Kemampuan berdakwah ini tidak hanya bertujuan untuk hal-hal keagamaan, tetapi juga berperan penting untuk hidup bersosial dengan anggota masyarakat lainnya. Dengan demikian, keterampilan berdakwah haruslah dimiliki oleh para siswa sejak dini.

Seni berbicara dalam berdakwah tidak terlepas dari kemampuan menyusun struktur materi dakwah, metode, strategi penyusunan oesan, dan memilih gaya dakwah yang tepat. Hal ini sangat berpengaruh pada ketercapaian tujuan dakwah. Memahami struktur materi dakwah dengan sistematis dan logis memudahkan pembicara dalam menyampaikan setiap pesan dan nasihat kepada pendengar. Dakwah yang terstruktur dengan baik juga berpengaruh pada kemudahan pendengar untuk memahami setiap pesan yang disampaikan da'i. Metode dakwah mempengaruhi ketertarikan pendengar akan isi ceramah yang disampaikan. Strategi penyampaian pesan diharuskan tidak monoton, sederhana dan mudah dipahami. Gaya dakwah penting dipahami untuk memahami karakter dan sikap komunikasi yang baik sesuai dengan tujuan dakwah.

Ustaz Yusuf Mansur salah satu da'i yang memiliki kemampuan retorika yang baik. Hal 
ini berdasarkan penelitian pendahuluan atas tanggapan pendengar Ustaz Yusuf Mansur yang menjelaskan bahwa bahasa dakwah Ustaz Yusuf Mansur sederhana, mudah dipahami sebesar 98\%, logis sebesar $86 \%$, dan menyentuh perasaan $80 \%$. Konten dakwah Ustaz Yusuf Mansur senantiasa mengajak kembali pada norma agama, umumnya berfokus pada tauhid, dan memberikan sugesti yang positif sebesar $94 \%$. Konten pesan yang disampaikan cenderung bervariatif selain perkara aqidah juga cenderung pada kebaharuan misalnya Keajaiban Sedekah, Ditolong Allah, dan Menjadi Pengusaha Yang Disayang Allah.

Retorika dakwah Ustaz Yusuf Mansur yang akan dianalisis pada bagian struktur, metode dakwah, strategi penyusunan pesan, serta pemilihan gaya dakwah yang tepat dapat dikemas menjadi satu bahan ajar berbicara yang menarik. Keterampilan berdakwah sebagai keterampilan berbicara perlu diasah dan dikembangkan pada siswa SMA. Umumnya, siswa merasa sulit menyusun struktur materi dakwah, metode, strategi komposisi pesan, dan gaya dakwah dalam berdakwah. Salah satu faktor yang mempengaruhi keterampilan berbicara berbasis religius yakni kenyataan bahwa terbatasnya bahan ajar keterampilan berbicara berbasis religius dalam bentuk CD interaktif. Bahan ajar audio visual tentunya sangat berpengaruh pada proses pembelajaran berbicara untuk menujukan contoh/model berupa gambar dan video yang berhubungan dengan kegiatan berbicara berbasis religius. Pemanfaatan penelitian berupa bahan ajar berbicara berbasis religius dalam bentuk CD interaktif dikarenakan kemampuan berbicara memiliki hubungan yang erat dengan kemampuan menyimak. Dengan demikian, bahan ajar dalam bentuk CD interaktif dirasa lebih tepat dibandingan bahan ajar dalam bentuk cetak dan lainnya.

Berdasarkan pemaparan di atas maka rumusan masalah dalam penelitian ini yakni

1. Bagaimanakah retorika dakwah Ustaz Yusuf Mansur?

a. Bagaimanakah struktur materi dakwah Ustaz Yusuf Mansur?

b. Bagaimanakah metode dakwah Ustaz Yusuf Mansur?

c. Bagaimanakah strategi penyusunan pesan Ustaz Yusuf Mansur?

d. Bagaimanakah gaya dakwah Ustaz Yusuf Mansur?

2. Bagaimanakah rancangan bahan ajar berbicara dan produk akhir bahan ajar berbicara dalam bentuk $C D$ interaktif untuk siswa SMA?

Retorika dakwah merupakan bagian khitabah atau public spekaking. Retorika dakwah merujuk pada dua istilah yakni istilah retorika dan istilah dakwah. Retorika berarti seni untuk berbicara baik yang dicapai berdasarkan bakat alam (talenta) dan keterampilan teknis. Dewasa ini retorika diartikan sebagai kesenian untuk berbicara baik, yang dipergunakan dalam proses komunikasi antarmanusia. Seni berbicara ini bukan hanya berarti berbicara lancar tanpa jalan pikiran yang jelas dan tanpa isi, melainkan suatu kemampuan untuk berbicara dan berpidato secara singkat, jelas, padat, dan mengesankan. Retorika mencakup pemahaman yang kuat, daya kreasi dan fantasi yang tinggi, teknik pengungkapan yang tepat dan daya pembuktian serta penilaian yang tepat. Retorika merupakan gabungan yang serasi antara pengetahuan, pikiran, kesenian dan kesanggupan berbicara. Dalam bahasa percakapan atau bahasa populer, retorika berarti pada tempat yang tepat, pada waktu yang tepat, atas cara yang lebih efektif, mengucapkan kata-kata yang tepat, benar dan mengesankan.

Lebih lanjut retorika mengandung dua pengertian, pertama pengertian sempit 
yaitu mengenai berbicara. Kedua pengertian luas yaitu penggunaan bahasa. Tidak heran jika ada yang mengatakan bahwa retorika itu hanya hal mengenai "berpidato". Retorika berdasarkan titik beratnya adalah seni atau kepandaian berbicara. Dapat disimpulkan bahwa retorika merupakan salah satu cabang ilmu pengetahuan yang secara khusus memusatkan perhatikan kepada tutur dan kegiatan bertutur (Oka, 1976, hlm.3)

Oka $(1976$, hlm. 65) menyebutkan beberapa fungsi retorika yang penting untuk dikuasi sebagai keterampilan berbicara, yakni antara lain:

1. retorika memberikan pengetahuan untuk memilih cara bertutur yang tepat

2. retorika mengajarkan cara menganalisa topik tutur secara persuasif-objektif

3. retorika melatih hal-hal yang perlu dipertimbangkan dalam rangka menemukan ulasan non-artistik

4. retorika memberikan pengetahuan untuk menempatkan bagian-bagian ulasan saat berbicara dengan tepat

5. retorika memberikan pengetahuan memilih gaya bahasa dan gaya berrbicara dalam penampilan (performance) ketika berbicara.

Retorika merupakan seni dalam keterampilan berbicara dan dakwah merupakan salah satu ragam keterampilan berbicara. Dakwah merupakan keterampilan berbahasa produktif. Produktif bermakna bahwa kegiatan dakwah bersifat aktif sesuai tujuan tertentu. Tujuan berbicara pun beragam mulai dari memberi informasi, mengajak, menegaskan, memberi sugesti bahkan memberikan. Ketercapaian tujuan pembicaraan seseorang tentunya tidak terlepas dari teknik berbicara atau teknik retorika dalam menyampaikan isi pembicaraan (Rakmat.2012, hlm.2)

Enjang dan Aliyudin (2012, hlm. 3) mengemukakan secara etimologis dakwah berarti: (1) memanggil, (2) menyeru, (3) menegaskan atau membela sesuatu, (4) perbuatan atau perkataan untuk menarik manusia kepada sesuatu, (5) memohon dan meminta, atau doa. Artinya, proses penyampaian pesan-pesan tertentu berupa ajakan, seruan, undangan, untuk mengikuti pesan tersebut atau menyeru dengan tujuan untuk mendorong seseorang agar melakukan cita-cita yang diinginkan.Kegiatan dakwah bertujuan untuk menyampaikan nasihat-nasihat, ajaran moral, dan nilai-nilai kebaikan. Selain itu, tujuan ceramah juga bertujuan untuk memberitahukan (informatif), mempengaruhi (persuasif), dan menghibur (rekreatif). Berdasarkan pendapat di atas, maka dapat disimpulkan bahwa retorika dakwah merupakan seni berbicara dalam hal berdakwah secara lisan yan dikenal dengan istilah ceramah.

Dakwah secara lisan tidak lepas dari penyusunan bagian-bagian dakwah yang dikenal dengan istilah struktur materi dakwah. Umumnya struktur materi dakwah merupakan komponen yang berperan sebagai tempat menyusun ide dan gagasan menjadi satu pesan dakwah yang utuh. Sistematika atau struktur isi dakwah perlu diperhatikan agar pesan menjadi runtut. Dakwah yang tersusun secara sistematis dan tertib akan menciptakan minat dan perhatian pendengar. Abidin, $(2012, \mathrm{hlm}$. 150) mengemukakan bahwa umumnya struktur isi dakwah terdiri atas tiga bagian utama yakni pendahuluan, pembahasan atau isi, dan penutup. Pendahuluan berfungsi sebagai pengantar. Pembahasan atau isi terdiri atas alasan, definsi, contoh, kisah, argumentasi pembicara, dan penutup merupakan bagian akhir yang berisi simpulan.

Pembukaan pidato, ceramah, dan ragam bicara public lainnya berfungsi memosisikan 
pikiran pendengar untuk bisa menerima pesan pada bagian isi hingga tuntas. Ma'arif (2014, hlm. 76) pembuka pidato atau ceramah bertujuan mengondisikan pendengar untuk penuh perhatian, dapat diatur, siap menerima pesan. Bagian pembuka umumnya berisi pujian kepada Allah Swt, shalawat kepada nabi, dan menyampaikan pujian kepada pendengar sebagai bentuk motivasi awal agar pendengar bersemangat. Bagian pembuka pidato atau ceramah hendaknya berupa stimulus atau pengantar menuju pesan utama.

Bagian isi merupakan bagian utama dari sebuah dakwah. Ma'arif (2010, hlm. 45)) mengemukakan bahwa isi dakwah hendaknya berupa definisi baik berhubungan dengan semantik ataupun ushul Fiqih, dalil yang bersumber dari Al-Qur'an dan hadist, pembahasan berupa contoh faktual dan aktual, kisah dan hikmah, argumentasi, pernyataan persuasif, wasiat (pesan) yang baik, diselingi humor edukatif serta pengulangan inti atau pokok dakwah. Bagian penutup merupakan bagian akhir dakwah. Abidin $(2013,173)$ mengemukakan bahwa penutup isi dakwah hendaknya berupa simpulan pembicaran, penekanan inti/pokok ceramah, mendorong pendengar untuk bertindak, harapan, doa, dan salam penutup.

Berdasarkan pemaparan pendapat pakar di atas, maka dapat disimpulkan bahwa struktur materi dakwah terdiri atas bagian pembuka, isi, dan penutup. Bagian pembuka merupakan bagian awal bersifat pendahuluan yang berisi salam pembuka dan pengantar bagian isi. Bagian pembuka umumnya berisi pujian kepada Allah, shalawat kepada rasul, memuji pendengar sebagai bentuk motivasi awal. Bagian pembuka dakwah dapat berupa: pemaparan pokok pokok persoalan, pengantar menuju inti dakwah, penjelasan peristiwa yang sedang diperingati, memaparkan sesuatu yang sesuai dengan suasana, emosi atau kepentingan pendengar. Bagian isi merupakan bagian utama yang berisi pemaparan mengenai pokok-pokok permasalahan yang dijelaskan lebih rinci. Bagian isi umumnya berupa pemaparan pesan utama dakwah yang meliputi: definisi baik berhubungan dengan semantik ataupun ushul Fiqih, dalil yang bersumber dari Al-Qur'an dan hadis, pembahasan berupa contoh faktual dan aktual, kisah dan hikmah, argumentasi, pernyataan persuasif, wasiat (pesan) yang baik, diselingi humor edukatif serta pengulangan inti atau pokok dakwah. Bagian penutup merupakan bagian akhir dakwah yang berisi simpulan pembicaran, penekanan inti atau pokok ceramah, mendorong pendengar untuk bertindak, harapan, doa, dan salam penutup.

Dalam kitab-kitab tafsir, Al-Hikmah dikemukakan sebagai berikut:, hujjah (argumentasi), akurat dan berfaedah untuk penetapan akidah atau keyakinan. Al-Hikmah sebagai perkataan yang sudah pasti benar, yaitu dalil yang menjelaskan kebenaran dan menghilangkan keraguan. la juga mengartikannya dengan Al-Quran, yakni "Serulah mereka untuk mengikuti kitab yang memuat al-hikmah". Wahbah al-Juhaili (dalam Enjang dan Aliyudin, 2009, hlm 90) memberi makna bi al- hikmah sebagai perkataan jelas dengan dalil yang jelas dan dapat mengantarkan pada jalan kebenaran dan menyingkap keraguan.

Menurut Ibnu Rusyd (Dalam Enjang dan Aliyudin, 2009, hlm. 88), dakwah dengan hikmah artinya dakwah dengan pendekatan substansi yang mengarah pada falsafah dengan nasihat yang baik, yang berarti retorika yang efektif dan populer, serta logis/ faktual atau dialektis yang unggul. Menurut Muhammad Husen Yusuf (Dalam Enjang dan Aliyudin, 2009, hlm. 100) metode dakwah dengan hikmah berarti dakwah yang disesuaikan dengan kadar akal, bahasa, dan lingkungan para pendengarnya. Dengan pemikirannya, ia menerima dakwah dengan mudah, selama dakwah itu tegak dan dijalankan sesuai dengan proporsinya. la tidak akan berbelit-belit dalam memahami pesan dakwah dan tidak ragu 
untuk melaksanakannya.

Metode dakwah Al-Hikmah merupakan metode dakwah dengan memberikan nasihat dan ajaran agama dengan kebenaran yang jelas. Dalil yang benar dalam dakwah bersumber dari Al-Qur'an dan hadis (Saputra, 2011, hlm. 246). Pemaparan isi dakwah dengan dalil yang benar bertujuan menghilangkan rasa ragu dan bimbang pendengar atas nasihat dan ajaran agama yang disampaikan dai.

Menambahkan konsep metode dakwah Al-Hikmah, Munir (2009, hlm. 12) mengemukakan bahwa metode dakwah Al-Hikmah memiliki konsep ketepatan. Ketepatan dalam memberikan tausiah ceramah disesuaikan dengan bahasa dan tingkat pemahaman pendengar dengan cara yang tepat. Dengan demikian, metode Al-Hikmah menekankan pada tiga hal yakni menyampaikan pesan dakwah dengan tepat, memilih bahasa sesuai pendengar dengan tepat, dan dengan cara yang tepat pula.

Al-Mauidzah Al-Hasanah menurut Enjang dan Aliyudin (2009, hlm. 89) memiliki pengertian sebagai berikut:

a. pelajaran dan nasihat yang baik, berpaling dari perbuatan jelek melalui tarhib dan targhib (dorongan dan motivasi), penjelasan, keterangan, gaya bahasa, peringatan, penuturan, contoh teladan, pengarahan, dan pencegahan dengan cara halus.

b. pelajaran, keterangan, penuturan, peringatan, pengarahan, dengan gaya bahasa yang mengesankan, atau menyentuh dan terpatri dalam naluri;

c. simbol, alamat, tanda, janji, penuntun, petunjuk, dan argumentatif (ucapan lembut dengan penuh kasih sayang);

d. kelembutan hati menyentuh jiwa dan memperbaiki peningkatan amal;

e. nasihat, bimbingan dan arahan untuk kemaslahatan. Dilakukan dengan baik dan penuh tanggung jawab, akrab, komunikatif, mudah dicerna, dan terkesan di hati sanubari mad'u.

f. suatu ungkapan dengan penuh kasih sayang yang terpatri dalam kalbu, penuh kelembutan sehingga terkesan dalam jiwa, tidak melalui cara pelanggaran dan pencegahan, sikap mengejek, melecehkan, serta menyudutkan atau menyalahkan

g. tutur kata yang lemah lembut, perlahan-lahan bertahap dan sikap kasih saying -dalam konteks dakwah- dapat membuat seseorang merasa dihargai rasa dan mendapat respon positif.

Metode dakwah Al-Mauidzah Al-Hasanah bermakna nasihat, bimbingan, pendidikan, dan peringatan. Saputra (2011, hlm 252) menjelaskan bahwa Metode dakwah Al-Mauidzah Al-Hasanah dapat diklasifikasikan dalam beberapa bentuk yakni: nasihat atau petuah, bimbingan, pengajaran dan pendidikan, kisah-kisah, kabar gembira dan peringatan, serta wasiat (pesan-pesan positif)

Pesan yang disampaikan kepada pendengar biasanya bersifat persuasif. Pesan tersebut berisi imbauan-imbauan agar pendengar dapat memahami dakwah dan dipraktikkan dalam kehidupan sehari-hari. Arbi (2012, hlm. 263) mengemukakan bahwa dalam menyampaikan dakwah hendaknya memperhatikan kesimbangan dalam memilih metode dakwah, strategi penyusunan pesan, dan penggunaan kata. Strategi memberikan imbauan bertujuan agar tujuan dakwah dapat tercapai. Pesan yang disampaikan antara lain: 
Salah satu strategi penyusunan pesan ialah dengan memaparkan pesan berupa imbauan rasional. Imbauan rasional didasarkan pada anggapan bahwa manusia pada dasarnya makhluk rasional yang baru bereaksi pada imbauan emosional apabila imbauan rasional tidak ada. Arbi (2012, hlm 263) mengemukakan bahwa imbauan rasional artinya meyakinkan orang lain dengan pendekatan logis atau penyajian bukti-bukti/fakta. Imbauan rasional ini berhubungan dengan strategi framing. Kekuatan pesan dalam memilih faktafakta yang dipahami oleh pembaca.

Senada dengan pedapat di atas Ma'arif (2010, hlm.50) memaparkan bahwa imbauan rasional mengacu pada logika pendengar. Pesan yang dilengkapi dengan fakta dan data lebih baik dibandingkan pesan yang berupa pendapat pribadi. Pesan yang rasional akan membuat pendengar dapat dengan mudah memahami bahkan meyakini kandungan pesan tersebut.

Imbauan emosional merupakan pesan yang berpengaruh bagi kepercayaan pendengar. Arbi (2012, hlm. 263 mengemukakan imbauan emosional menggunakan pernyataanpernyataan atau bahasa yang menyentuh emosi komunikan. Imbauan emosional juga dapat diartikan sebagai pesan yang menyentuh perasaan atau emosi pendengar. Memperkuat pendapat di atas, Ma'arif (2010, hlm. 51) mengemukakan bahwa imbauan emosional lebih efektif bagi komunikasi persuasi. Hal ini dikarenakan, manusia memiliki kecenderungan mengikuti perasaan dan hal-hal yang menggugah emosi. Setelah menyentuh emosi pendengar, dilanjutkan dengan pemaparan bukti dan alasan yang meyakinkan logika pendengar. Hal ini dilakukan untuk menciptakan komunikasi persuasif yang efektif.

Imbauan pesan lainnya yakni imbauan takut. Arbi, (2012, hlm. 263) mengemukakan bahwa imbauan takut berupa pesan yang bersifat mencemaskan, mengancam, atau meresahkan. Imbauan pesan ini efektif untuk menanamkan pondasi untuk tunduk dan patuh terhadap ajaran agama. Memperkuat pendapat di atas, Ma'arif (2010, hlm. 51) mengemukakan bahwa pesan takut merupakan pesan yang berisi kekhawatiran, ancaman, kecemasan yang menimbulkan ketakutan. Jenis imbauan ini umumnya digunakan untuk menciptakan rasa takut berbuat hal-hal yang tidak dibenarkan oleh norma agama.

Imbauan ganjaran menurut Arbi (2012, hlm. 263) menegaskan bahwa imbauan ganjaran merujuk pada hal-hal yang menjanjikan pada sesuatu yang diinginkan dan tidak diinginkan. Imbauan ganjaran ini dapat memperkuat amalan ibadah sebab memberikan pemahaman terhadap reward dan punishment atas apa yang telah diperbuat.

Ma'arif (2010, hlm. 51) juga menegaskan bahwa imbauan ganjaran berupa sebabakibat yang diperoleh ketika melakukan sesuatu. Istilah dosa dan pahala merupakan bagian dari imbauan ganjaran. Selain itu, aspek ganjaran juga sangat berhubungan dengan dalildalil Al-Qur'an dan hadis mengenai setiap keutamaan atau faedah melakukan ibadah-ibadah sunah dan penjelasan konsekuensi atas setiap perbuatan yang berakhir pada surga dan neraka. Serta Imbauan motivasional menggunakan imbauan motif (motive appeals) yang menyentuh kondisi hati atau diri manusia dari dalam. Imbauan motivasional ini mengacu pada dorongan atau keinginan-keinginan agar suatu perbuatan yang dilakukan akan memperoleh. Dalam Al-Qur'an dorongan atau motivasi berupa janji-janji kehidupan yang lebih baik jika hidup dengan penuh rasa syukur. Ma'arif, (2010, hlm. 44) mengemukakan bahwa pesan imbauan motivasional merupakan pesan yang mengandung dorongan untuk berbuat dengan tujuan tertentu disertai dengan ajakan dan harapan.

Retorika dakwah sebagai suatu seni berbicara tentunya menuntut inovasi dan 
kreatifitas da'i dalam penyampaian dakwah. Dakwah yang bertujuan memberi nasihat dan mengajak pendengar kembali pada ajaran agama hendaknya disampaikan dengan gaya atau style yang menarik. Setiap da'i atau pembicara publik memiliki gaya khas dalam berbicara dan berkomunikasi pada pendengar. Ma'arif (2010, hlm. 134) mengemukakan bahwa setiap pembicara memiliki gaya yang khas. Tidak menutup kemungkinan bahwa pembicara atau atau da'i memiliki lebih dari satu gaya dakwah dalam berkomunikasi. Ada Sembilan gaya dakwah yakni. Dominan, dramatik, pendebat, bergelora, meninggalkan kesan, santai, penuh perhatian, terbuka, dan bersahabat.

Gaya dakwah juga meliputi kekhasan diksi dan gaya bahasa yang digunakan Ustaz Yusuf Mansur. Diksi merupakan ketepatan dalam pemilihan kata-kata. Dalam konteks gaya dakwah, deskripsi diksi lebih mengacu pada kata-kata khas yang digunakan seseorang ketika berdakwah. Kridalaksana (1993, hlm. 40) mengemukakan bahwa diksi adalah pilihan kata dan kejelasan lafal untuk memperoleh efek tertentu dalam berbicara di depan umum. Ada beberapa bentuk diksi yang umumnya dipakai pembicara yaitu (1) kata umum dan kata khusus, (2) kata ilmiah dan kata popular, (3) kata percakapan dan kata sapaan. Serta ada empat gaya bahasa yakni gaya bahasa penegasan, perbandingan, pertentangan, dan sindiran.

Bahan ajar merupakan komponen pembelajaran yang penting. Bahan ajar dapat membantu siswa memahami materi pelajaran dan kompetensi yang harus dicapai siswa. Bahan ajar memiliki berbagai jenis dan bentuk. Bahan ajar terbagai berdasarkan beberapa klasifikasi yakni berdasarkan bentuk, cara kerja, dan sifatnya. Prastowo (2014, hlm. 40) mengemukakan bahan ajar menurut bentuknya terbagi atas bahan ajar cetak, bahan ajar dengar, bahan ajar pandang dengar (audio visual), dan bahan ajar interaktif. Kemudian, bahan ajar menurut cara kerjanya terdiri atas bahan ajar yang tidak diproyeksikan, bahan ajar yang diproyeksikan, bahan ajar audio (memerlukan sinyal audio), bahan ajar video (memerlukan alat memutar video, bahan ajar media. Selanjutnya, bahan ajar menurut sifatnya terbagi menjadi bahan ajar berbasiskan cetak, bahan ajar yang berbasiskan teknologi, bahan ajar yang digunakan untuk praktik atau proyek, dan bahan ajar yang diperlukan untuk interaksi manusia.

Bahan ajar interaktif menurut Prastowo $(2014, \mathrm{hlm}$. 329) ialah bahan ajar berupa kombinasi dari dua atau lebih media (audio, teks, grafik, gambar, animasi, dan video). Saat ini, banyak kegiatan pembelajaran menggunakan bahan ajar interaktif karena menarik dan juga mempermudah penggunanya dalam mempelajari suatu bidang tertentu. Bisaanya bahan ajar multimedia interaktif dirancang secara lengkap mulai dari petunjuk penggunaannya hingga penilaian.

Bahan ajar berbicara dalam bentuk CD interaktif dibuat dengan terlebih dahulu merancangan GBPM, flowchart, storyboard, serta desain pembelajaran dan RPP. Bahan ajar interaktif dikembangan dengan model tutorial. Model tutorial adalah pembelajaran melalui komputer siswa dikondisikan untuk mengikuti alur pembelajaran yang sudah terprogram dengan penyajian materi dan latihan soal. Model tutorial sangat menuntut siswa menguasai materi secara tuntas, sehingga sebelum setiap segmen materi terkuasai belum bisa berlanjut ke materi berikutnya. Tutorial berisi: tujuan, materi, dan evaluasi, tujuan model tutorial adalah memberikan pemahaman secara tuntas (mastery learning) kepada siswa mengenai materi pelajaran yang dipelajari dalam format flash. 


\section{METODE PENELITIAN}

Metode yang digunakan dalam penelitian ini merupakan metode deskriptif analisis. Metode ini digunakan karena sesuai dengan acuan penelitian yang bersifat kualitatif.. Metode penelitian deskriptif analisis merupakan suatu cara pemecahan masalah dengan cara menggambarkan suatu objek. Objek yang akan digambarkan terbatas pada usaha mengungkapkan suatu masalah, keadaan, atau peristiwa sebagaimana adanya, sehingga bersifat mengungkapkan fakta. Metode deskriptif analisis juga dapat diartikan sebagai prosedur pemecahan masalah yang diteliti dengan memaparkan fakta atau melukiskan keadaan berdasarkan fakta yang nampak dan bersifat apa adanya.

Sumber data penelitian yakni dakwah Ustaz Yusuf Mansur berupa video dan MP3 yang terdiri atas 4 ceramah Ustaz Yusuf Mansur yang berjudul: 1) 10 Dosa Besar Vol.2, 2). Libatkanlah Segala Urusan Bersama Allah, 3) Allah Dulu, Allah Lagi, Allah Terus, 4) Ditolong Allah. Data penelitian ini ialah tuturan dakwah Ustaz Yusuf Mansur yang memiliki durasi berbeda-beda. Ceramah berjudul 10 Dosa Besar Vol.2 berdurasi 51 menit, Libatkanlah Segala Urusan Bersama Allah berdurasi 41 menit, Allah Dulu, Allah Lagi, Allah Terus berdurasi 35 menit dan ceramah berjudul Ditolong Allah berdurasi 21 menit. Tuturan dakwah Ustaz Yusuf Mansur kemudian ditranskripsikan dalam bentuk tulisan. Hasil transkripsi dakwah Ustaz Yusuf Mansur akan dianalisis dengan menggunakan instrumen analisis data yang telah divalidasi oleh tujuh ahli dibindang ilmu komunikasi dakwah.

Teknik yang digunakan untuk memperoleh data transkripsi dakwah Yusuf ialah teknik simak, catat, dan teknik dokumentasi. Teknik analisis data adalah cara-cara yang digunakan untuk menganalisis atau mengolah data yang terkumpul atau diperoleh dari penelitian yakni dengan melakukan identifikasi, klasifikasi, penyajian data dan analisis retorika dakwah, analisis angket tanggapan pendengar, dan perancanaan bahan ajar berbicara dalam bentuk CD interaktif untuk siswa SMA. Tahap perancanaan bahan ajar dalam bentuk CD interaktif berupa GBPM, flowchart, storyboard

\section{HASIL DAN PEMBAHASAN}

\section{Struktur Materi Dakwah}

Struktur materi dakwah Yusuf Mansur dianalisis dengan mengidentifikasi, klasifikasi, dan analisis tuturan dakwah Yusuf Mansur pada empat judul ceramah Yusuf Mansur. Pada judul ceramah 10 Dosa Besar yang disampaikan Yusuf Mansur secara keseluruhan terdiri atas Transkripsi judul dakwah 10 Dosa Besar Vol 2 secara keseluruhan berjumlah 5.808 kata yang terdiri atas bagian pembuka berupa pujian kepada Allah Swt dan shalawat kepada Rasulullah Saw serta memuji jemaah 70 kata, bagian isi dakwah berupa kisah 2199 kata, contoh 1670 kata, dalil Al-Qur'an 623 kata, materi dakwah berupa definisi dan penjelasan 295, wasiat 289 kata, nasihat 145 kata, pengulangan inti dakwah 123 kata, serta bagian penutup berupa doa dan salam penutup 394 kata. Secara umum, struktur materi dakwah Yusuf Mansur tampak pada tabel berikut ini: 
Judul dakwah: 10 Dosa Besar vol.2

Tanggal dakwah: 28 Agustus 2008

Durasi ceramah: 51 Menit

Format file: DVD Movie

\begin{tabular}{|c|c|c|c|}
\hline $\begin{array}{l}\text { Judul Cer- } \\
\text { amah }\end{array}$ & $\begin{array}{l}\text { Struktur } \\
\text { Dakwah }\end{array}$ & Tuturan Dakwah & Bentuk \\
\hline \multirow[t]{3}{*}{10 Dosa Besar } & Pembuka & $\begin{array}{l}\text { Assalammualaikum Warahmatullahi Wa- } \\
\text { barakatu Allahhuma salim wabarik ala } \\
\text { sayyidina Muhammad waa ala ali. Wal- } \\
\text { hamdulillahi robbil alamin. Bapak ibu yang } \\
\text { dirahmati Allah. Memang kalau sudah } \\
\text { urusan anak ama urusan istri emang ini } \\
\text { masya Allah, Kita semua bekorban dan } \\
\text { hari ini kita hadir di sini pun mengorban- } \\
\text { kan banyak hal, mengorbankan waktu } \\
\text { Saturday, yang harusnya weeken for our } \\
\text { family for our childrent tapi kita ada disi- } \\
\text { ni, subhanaAllah, mudah-mudahan Allah } \\
\text { menghitung ini sebagai sebuah rahmat } \\
\text { buat kita, aamiin. }\end{array}$ & $\begin{array}{l}\text { Salam pem- } \\
\text { buka shalawat } \\
\text { kepada Rasu- } \\
\text { lulloh Saw dan } \\
\text { memuji pen- } \\
\text { dengar }\end{array}$ \\
\hline & Isi & $\begin{array}{l}\text { Kemarin pembahasan kita sampai kepa- } \\
\text { da si Ayah dan si Ibu yang sudah } 7 \text { tahun } \\
\text { tidak bekerja. Suaminya itu datang meng- } \\
\text { hadap pada saya. Lalu dia bertanya, mem- } \\
\text { inta kepada saya suatu amalan yang bisa } \\
\text { membuat dia naik. } 1 \text { hal sebenarnya yang } \\
\text { saya amati dari perjalanan hidup saya dan } \\
\text { perjalanan hidup orang-orang yang sholeh } \\
\text { dan saya berusaha untuk menuju pada itu. } \\
\text { Bahwa menujulah kepada Allah. }\end{array}$ & $\begin{array}{l}\text { Kisah dan } \\
\text { wasiat }\end{array}$ \\
\hline & Penutup & $\begin{array}{l}\text { Barakallah, kita terusin nanti. Ada satu } \\
\text { sesi zina emang mau saya pisahin, karena } \\
\text { ini penyakit nih. Ini penyakit betul ni. Jadi } \\
\text { saya pikir, kita harus khawatir ama anak- } \\
\text { anak kita terutama. Dialog saya kepada } \\
\text { dia dan secara ajaib bagaimana kisahnya } \\
\text { besok pagi ada orang datang kepada dia } \\
\text { mengabarkan sedangkan saya ... }\end{array}$ & $\begin{array}{l}\text { Penekanan } \\
\text { pokok dakwah, } \\
\text { wasiat, dan } \\
\text { kisah }\end{array}$ \\
\hline
\end{tabular}

Pada data di atas terlihat bagian pembuka materi dakwah Yusuf Mansur terdiri atas salam pembuka, shalawat Rasululloh Saw, dan pujian kepada pendengar. Setelah menyampaikan bagian pembuka materi dakwah, Yusuf Mansur kemudian menyampaikan materi dakwah dan mengawalinya dengan menyampaikan kisah nyata yang pernah dialami ketika melaksanakn konseling dosa besar. Setelah menyampaikan kisah, Yusuf Mansur memberikan wasiat agar dalam hidup senantiasalah menuju kepada Allah. Bagian isi 
dijelaskan panjang lebar dengan menceritakan banyak contoh, kisah, wasiat, dalil Al-Qur'an, dll. Bagian penutup materi dakwah Yusuf Mansur berupa penekanan pokok materi dakwah, wasiat, mengulas kisah, doa, dan salam penutup.

\section{Metode Dakwah}

Secara keseluruhan metode dakwah yang dominan digunakan Ustaz Yusuf Mansur ialah metode Al- Mauizah Al- Hasanah berupa contoh, kisah, wasiat, dan lainnya. Kemudian, metode yang digunakan Yusuf Mansur dalam menyampaikan dakwah secara lisan juga berupa metode Al-Hikmah.

Judul Dakwah: Libatkan Segala Urusan Bersama Allah

Tanggal dakwah: 12 Januari 2013

Durasi dakwah: 41 Menit

Format file: Winamp File

\begin{tabular}{|c|c|c|c|}
\hline Judul Ceramah & $\begin{array}{l}\text { Metode } \\
\text { Dakwah }\end{array}$ & Tuturan Dakwah & Bentuk \\
\hline \multirow[t]{2}{*}{$\begin{array}{l}\text { Libatkan Segala } \\
\text { Urusan Bersama } \\
\text { Allah }\end{array}$} & $\begin{array}{l}\text { Al- Mauizah } \\
\text { Al- Hasanah }\end{array}$ & $\begin{array}{l}\text { Saya pernah duduk satu bangku } \\
\text { pejabat dari pusat yang saya yakin } \\
\text { orang-orang yang kami lewati sudah } \\
\text { tau siapa yang ada di mobil tersebut. } \\
\text { Tapi mungkin informasi sudah menye- } \\
\text { bar bahwa ada orang sangat berkuasa } \\
\text { lewat. Lalu untuk yang menghormati } \\
\text { orang yang sangat berkuasa ini kepala } \\
\text { daerah memerintahkan semua murid- } \\
\text { murid keluar memegang bendera me- } \\
\text { rah putih. Lalu saya kedapetan duduk } \\
\text { di salah satu mobil pembantunya yang } \\
\text { sangat berkuasa. Apa yang terjadi bap- } \\
\text { ak ibu yang dirahmati Allah? Saya meli- } \\
\text { hat sebuah keanehan untuk pelajaran } \\
\text { buat saya sendiri. Padahal Allah turun } \\
\text { dengan segenap malaikat-malaikatnya } \\
\text { di waktu sholat boro-boro kita perha- } \\
\text { tian kepada Dia. Ini tanda kita tidak } \\
\text { mengenal Dia sama sekali . }\end{array}$ & Kisah \\
\hline & Al-Hikmah & $\begin{array}{l}\text { Apa sih yang menjadi urusan kita se- } \\
\text { mua? Apa yang menjadi hajat kita } \\
\text { semua nomor satu iman yang bisa } \\
\text { menyelesaikannya, yang bisa menger- } \\
\text { akkan, yang bisa memberi jawaban, } \\
\text { yang bisa kemudian memberikan so- } \\
\text { lusi atas segala hajat masalah iman } \\
\text { pribadi, iman negara adalah Allah sub- } \\
\text { hanahuwataala }\end{array}$ & $\begin{array}{l}\text { Kebenaran } \\
\text { mutlak }\end{array}$ \\
\hline
\end{tabular}


Pada data di atas terlihat dalam menyampaikan materi dakwah Yusuf Mansur menceritakan kisah yang pernah dialami. Kemudian, Yusuf Mansur juga menyampaikan konsep-konsep tauhid yang kebenaran yang bersifat mutlak bahwa iman kepada Allah adalah solusi dalam menghadapi masalah apapun. Iman adalah pondasi utama membentuk kehidupan yang lebih baik. Secara keseluruhan, transkripsi judul dakwah Libatkan Segala Urusan Bersama Allah secara keseluruhan berjumlah 3.959 kata yang terdiri atas tuturan dakwah kategori metode dakwah Al-Hikmah 738 kata dan kategori metode dakwah AlMauizah Al- Hasanah 3.221 kata.

\section{Strategi Penyusunan Pesan}

Strategi penyusunan pesan merupakan penyusunan pesan dakwah yang disampaikan dari segi psikologi pesan yang terdiri atas imbauan rasional, emosional, ganjaran, takut, dan motivasional. Imbauan yang digunakan Yusuf Mansur dalam menyampaikan pesan dakwah dapat dikatakan bervariasi sebagaimana data berikut ini:

Judul Dakwah: Allah Dulu, Allah Lagi, Allah Terus

Tanggal Dakwah: 25 Juni 2014

Durasi Dakwah: 35 Menit

Format File: MP3

\begin{tabular}{|c|c|c|}
\hline $\begin{array}{l}\text { Judul } \\
\text { Ceramah }\end{array}$ & Tuturan Dakwah & $\begin{array}{l}\text { Strategi } \\
\text { Penyusunan } \\
\text { Pesan }\end{array}$ \\
\hline \multirow[t]{2}{*}{$\begin{array}{l}\text { Allah } \\
\text { Dulu, Al- } \\
\text { lah Lagi, } \\
\text { Allah } \\
\text { Terus }\end{array}$} & $\begin{array}{l}\text { Kalau kita sepakati siapa tuhan kita, yakni Allah maka kita } \\
\text { kudu tau tidak ada yang bisa bikin kita senang kecuali Allah. } \\
\text { Tidak ada yang bisa bikin kita jadi nangis kecuali Allah. Tidak } \\
\text { ada yang bisa bikin kita bahagia kecuali Allah. Tidak ada yang } \\
\text { bisa bikin kita jadi menderita juga kecuali Allah. Tidak ada } \\
\text { yang bisa bikin kita jadi punya duit kecuali Allah. Tidak ada } \\
\text { yang bisa bikin kita jadi ilang duit kecuali Allah. Tidak ada } \\
\text { yang bisa bikin kita jadi kaya kecuali Allah. Tidak ada yang } \\
\text { bisa bikin kita jadi miskin kecuali Allah. Tidak ada yang bisa } \\
\text { bikin kita jadi mudharat kecuali Allah. Tidak ada yang bisa } \\
\text { bikin kita jadi manfaat juga kecuali Allah. Tidak ada yang bisa } \\
\text { menghidupkan kecuali Allah. Dan tidak ada yang bisa mema- } \\
\text { tikan juga kecuali Allah. }\end{array}$ & $\begin{array}{l}\text { Imbauan } \\
\text { emosional }\end{array}$ \\
\hline & $\begin{array}{l}\text { Afaroaitum ma tumnun aantum takhlukum nahnu } \\
\text { kholiqun, liat ciptaanKu liat ciptaan Allah siapa tuh yang ny- } \\
\text { iptain? Ternyata yang menciptakan adalah Allah, bukan kita. } \\
\text { Afaroaitum mah tahrusun, liat tuh tumbuh-tumbuhan yang } \\
\text { kita makan siapa yang kemudian bikin dia jadi numbuh? Bah- } \\
\text { kan termasuk metiknya makannya siapa? Afaroaitulmu ma } \\
\text { allazi tasyrobun, siapa yang bikin air yang kamu minum jadi } \\
\text { turun jadi memancar dari bumi. Afaroaitummun narollazi } \\
\text { tuuru, siapa yang kemudian membuat api ketika kalian per- } \\
\text { cikkan jadi memercik, siapa? Inilah dia tauhid. }\end{array}$ & $\begin{array}{l}\text { Imbauan } \\
\text { rasional }\end{array}$ \\
\hline
\end{tabular}


Pada data di atas, terlihat imbauan pesan dalam dakwah Yusuf Mansur berupa imbauan rasional dan juga emosional. Imbauan rasional digunakan untuk mempengaruhi ranah logika. Imbauan emosional digunakan untuk mneyentuh perasaan pendengar. Kedua jenis imbauan pesan ini baik digunakan untuk meningkatkan pemahaman, kepercayaan, dan mempengaruhi pendengar untuk berbuat sesuai dengan norma agama.

\section{Gaya Dakwah}

Gaya dakwah terdiri atas gaya komunikasi, diksi, dan gaya bahasa khas (style) Yusuf Mansur dalam berdakwah. Gaya komunikasi dakwah Yusuf Mansur berdasarkan analisis simakkan dakwah Yusuf Mansur pada empat judul ceramah yakni 10 Dosa Besar Vol 2, Libatkan Segala Urusan Bersama Allah, Allah Dulu, Allah Lagi, Allah Terus, dan Ditolong Allah maka dapat dideskripsikan Yusuf Mansur miliki gaya komunikasi yang bersahabat, santai, terbuka, dan berkesan. Ada pun diksi dan gaya bahasa khas Yusuf Mansur yakni sebagai tabel berikut ini:

Judul Dakwah: Ditolong Allah

Tanggal Dakwah: 5 Juni 2012

Durasi Dakwah: 20 Menit

Format File: Mp3

\begin{tabular}{|c|c|c|c|c|}
\hline \multirow[b]{2}{*}{$\begin{array}{l}\text { J u d u I } \\
\text { Ceramah }\end{array}$} & \multirow[b]{2}{*}{ Tuturan Dakwah } & \multicolumn{3}{|c|}{ Kategori Diksi } \\
\hline & & $\begin{array}{l}\text { Kata } \\
\text { Ilmiah }\end{array}$ & $\begin{array}{l}\text { Kata } \\
\text { Populer }\end{array}$ & $\begin{array}{l}\text { Kata } \\
\text { Percakapan }\end{array}$ \\
\hline $\begin{array}{l}\text { Ditolong } \\
\text { Allah }\end{array}$ & $\begin{array}{l}\text { Bismillahirahmannirohim. Assalam- } \\
\text { mualaikum Wr Wb. Kita langsung hata- } \\
\text { man Qur'an dulu ayat yang ke-25 surat } \\
\text { An-Nisa. Ihamdulilah, pagi-pagi kita su- } \\
\text { dah ngatamin Qur'an bareng Saudara- } \\
\text { Saudara yang dirahmati Allah. Siap, } \\
\text { oke ada pertanyaan menarik dari Yusuf } \\
\text { Mansur, siapa sebenarnya tuhan Anda? } \\
\text { Siapa pemberi rezki Anda? Siapa pen- } \\
\text { jamin hidup Anda? Kenalkah Saudara } \\
\text { dengan tuhan Anda? Oke pertanyaan- } \\
\text { nya sederhana ini ada juga di CD Kun } \\
\text { Faya Kun bahwa Saudara-Saudara yang } \\
\text { berkenan membuat off airnya membuat } \\
\text { kemudian pertemuan-pertemuan den- } \\
\text { gan jemaah dengan simpul dan lain-lain } \\
\text { Saudara cukup mengorder CD Kun Faya } \\
\text { Kun. Ini CD cakep banget ni, CD ini per- } \\
\text { tama kali dirilis tahun } 2004 \text { atau } 2005 \\
\text { gitu Kun Faya Kun sebagaimana juga } \\
\text { ada di buku Kuliah Tauhid ini Saudara. }\end{array}$ & & $\begin{array}{l}\text { Off air, } \\
\text { mengor- } \\
\text { der, oke }\end{array}$ & $\begin{array}{l}\text { Ngatamin, } \\
\text { b a re } n g, \\
\text { c a k e } p, \\
\text { banget, nih, } \\
\text { dan gitu }\end{array}$ \\
\hline
\end{tabular}


Pada data di atas, terlihat diksi yang digunakan Yusuf Mansur mrupakan diksi percakapan sehari-hari. Penggunaan diksi percakapan sehari-hari menciptakan suasana akrab dan dekat dengan pendegar. Adanya ciri khas dialek Betawi merupakan diksi khas Yusuf Mansur yang sering didengar dalam dakwah yang beliau sampaikan. Gaya bahasa yang khas digunakan Yusuf Mansur akan tampak pada tabel berikut:

\begin{tabular}{|c|c|c|c|c|c|}
\hline & & \multicolumn{4}{|c|}{ Kategori Gava Bahasa } \\
\hline $\begin{array}{l}\text { J u d u I } \\
\text { Ceramah }\end{array}$ & Tuturan Dakwah & $\begin{array}{l}\text { Gaya Bahasa } \\
\text { Penegasan }\end{array}$ & $\begin{array}{l}\text { G a y a } \\
\text { Bahas a } \\
\text { Sindiran }\end{array}$ & $\begin{array}{l}\text { Gaya Bahasa } \\
\text { Pertentangan }\end{array}$ & $\begin{array}{l}\text { Gaya Ba- } \\
\text { hasa Per- } \\
\text { bandingan }\end{array}$ \\
\hline $\begin{array}{l}\text { Ditolong } \\
\text { Allah }\end{array}$ & $\begin{array}{l}\text { Pemirsa yang } \\
\text { dirahmati Allah, kalau } \\
\text { sampai Saudara tidak } \\
\text { merasa ada Allah di sisi } \\
\text { Saudara itu hati Saudara } \\
\text { perlu diperiksa. Bisa jadi } \\
\text { bukan karena gak kenal } \\
\text { tapi Allah gak masuk ke } \\
\text { dalam karena barangkali } \\
\text { terlalu banyak dosa-dosa } \\
\text { kita semua. Kita berdoa } \\
\text { kepada Allah subhana- } \\
\text { huwataala begitu kita } \\
\text { susah jeebret kayak } \\
\text { saya ingatin tadi di awal } \\
\text { kita kayak ban kempes } \\
\text { langsung ingat ke tu- } \\
\text { kang tambal ban, kita } \\
\text { kayak si sakit ingat ke } \\
\text { dokter, kita kayak kemu- } \\
\text { dian lapar ingat ke nasi, } \\
\text { kita kayak haus ingat } \\
\text { ke minum. Jadi begitu } \\
\text { kita kaya,miskin, susah, } \\
\text { senang, dapat bonus, il- } \\
\text { ang bonus, dapat duit, } \\
\text { ilang duit, dapat mobil, } \\
\text { ilang mobil, dapat ker- } \\
\text { jaan, ilang kerjaan, every } \\
\text { momen kita datang ke } \\
\text { Allah kita ingat kepada } \\
\text { Allah. }\end{array}$ & $\begin{array}{l}\text { Antiklimaks: } \\
\text { mengung- } \\
k \text { a } p \text { k a } n \\
\text { g a g a s a n } \\
\text { ko m p leks } \\
\text { menuju ga- } \\
\text { gasan se- } \\
\text { d e r h a n a } \\
\text { yakni men- } \\
\text { genai hati } \\
\text { yang perlu } \\
\text { dipe riks a } \\
\text { jika tidak } \\
\text { merasa ada } \\
\text { Allah Swt di } \\
\text { dalamnya. }\end{array}$ & & $\begin{array}{l}\text { Antithesis: } \\
\text { mengung- } \\
\text { kapkan ber- } \\
\text { bagai lawan } \\
\text { kata dalam } \\
\text { satu kali- } \\
\text { mat seperti } \\
\text { kaya, mis- } \\
\text { kin, susah, } \\
\text { senang dan } \\
\text { lainnya. }\end{array}$ & \\
\hline
\end{tabular}


Pada tabel di atas terlihat penggunaan gaya bahasa khas Yusuf Mansur ialah gaya bahasa penegasan. Gaya bahasa penegasan yang dominan berupa repetisi, retoris, klimaks, dan antiklimaks. Yusuf Mansur senantiasa mengulang kata, frasa, atau kalimat yang dianggap penting kepada pendengar. Dalam menyampaikan pesan dakwah, Yusuf Mansur sering memulai dari penyampaian pesan sederhana menuju pesan yang bersifat lebih rumit. Selain gaya bahasa penegasan, Yusuf Mansur juga menggunakan gaya bahasa perbandingan yakni gaya bahasa alegori, simile, litotes, dan personifikasi.

\section{Bahan Ajar Berbicara dalam Bentuk CD Interaktif}

Hasil temuan retorika dakwah Ustaz Yusuf Mansur kemudian dijadikan rancangan pembelajaran yakni dengan membuat desain pembelajaran, RPP, GBPM, Flowhart, storyboard multimedia bahan ajar berbicara. Tahap pembelajaran siswa yakni siswa telah mempersiapkan PC atau laptop dan telah menyimpan program flash berisi materi pembelajaran interaktif. Bahan ajar yang dibuat terdiri atas bagian pembuka, penyajian materi secara lengkap dengan ikon menu tampilan yang terdiri atas pengertian ceramah, konten ceramah, diksi, aspek penampilan dalam ceramah, model ceramah Yusuf Mansur, latihan dan bagian penutup Siswa menggunakan bahan ajar iinteraktif sesuai petunjuk penggunaan bahan ajar. siswa dapat memahami materi dengan membaca materi yang telah disajikan. Setelah siswa memahami konsep ceramah maka untuk menguatkan pemahaman siswa tentang praktik berceramah siswa dapat melihat model yang disediakan yakni dua ceramah Ustaz Yusuf Mansur dalam bentuk video dan audio agar siswa dapat memahami bagaimana berceramah dengan lafal, intonasi, jeda, dan ekpresi. Setelah melihat konten materi, bahan ajar berbicara ini memberikan peluang interaksi siswa (feed back) dalam bentuk tes benar salah yang harus dijawab berdasarkan video ceramah Yusuf Mansur yang telah dilihat dan materi yang dipaparkan.

Selanjutnya, siswa diarahkan untuk melaksanakan evaluasi dengan mengklik menu evaluasi. Menu evaluasi berisi instruksi agar siswa praktik berceramah dengan mempersiapkan teks ceramah. Siswa dapat memilih salah satu judul ceramah yang telah disediakan, menentukan konteks ceramah, menggumpulkan bahan yang sesuai dengan judul ceramah, membuat kerangka ceramah dan mengembangkan kerangka ceramah. Teks ceramah dibuat berdasarkan struktur, metode, dan variasi jenis pesan sehingga menjadi satu teks ceramah yang utuh dan menarik sebagaimana model teks ceramah yang telah disajikan di dalam bahan ajar setelah siswa menyelesaikan teks ceramah, siswa dapat berlatih berceramah dengan lafal, intonasi, dan ekpresi yang baik menggunakan bahan ajar berbicara dalam bentuk CD interaktif. Latihan dan Penampilan ceramah siswa dapat langsung direkam dengan aplikasi program recording dan webcam yang telah disediakan dalam CD interaktif. Rekaman akan dimulai dengan mengklik tombol start dan akan berhenti setelah mengklik tombol stop. Pelaksanaan evaluasi memerlukan perangkat tambahan yakni earphone untuk memaksimalkan suara yang direkam dan tersimpan setelah menekan tombol berhenti. File rekaman ceramah siswa dapat tersimpan dan dilihat kembali sebagai penilaian otentik. Penampilan siswa berupa ekspresi, lafal, intonasi, jeda, dan aspek lainnya dapat dinilai dengan baik berdasarkan hasil rekaman ceramah siswa. Berikut flowchart bahan ajar interaktif dalam hal berceramah untuk siswa SMA. 


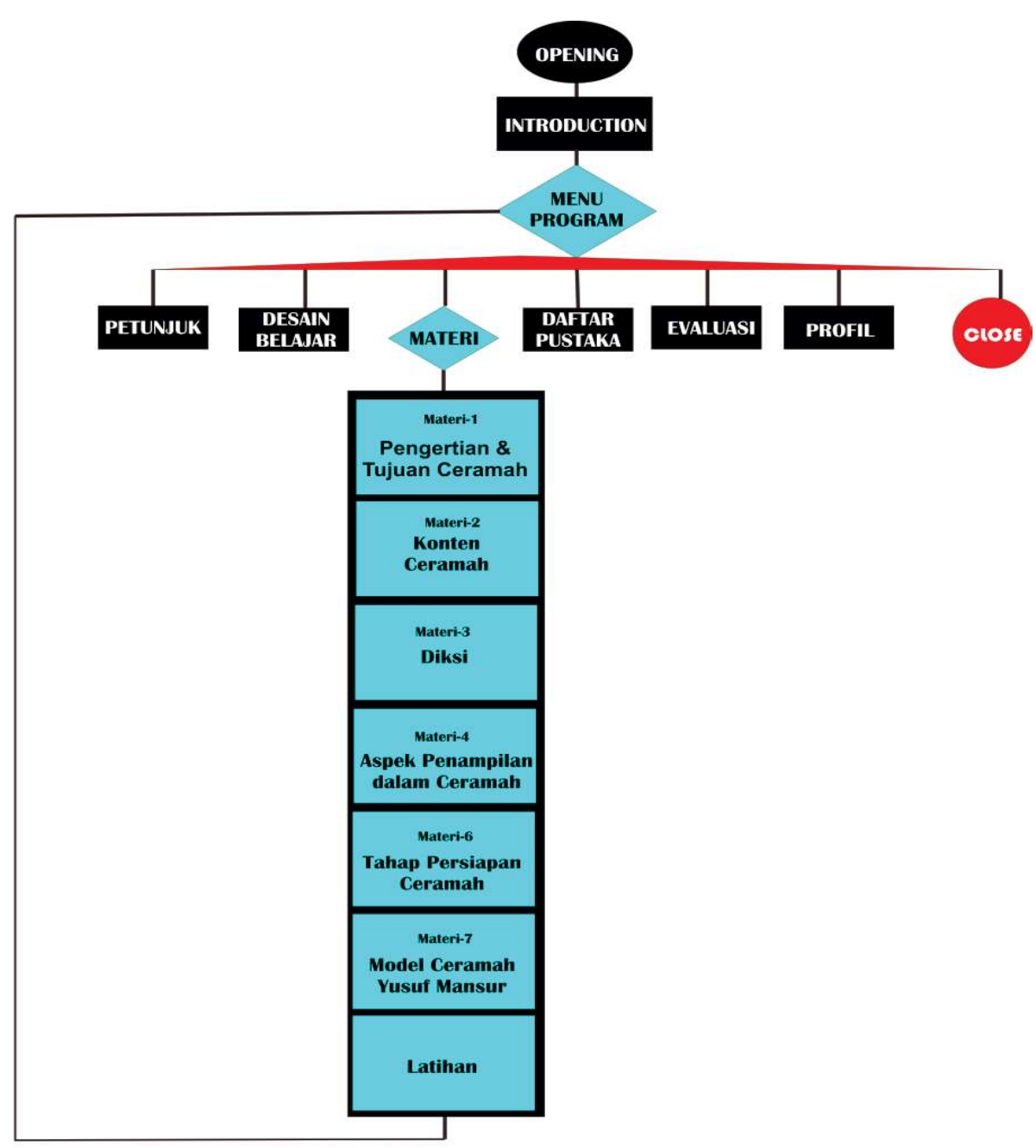

\section{Simpulan}

Kepribadian dan retorika dakwah memiliki peran penting dalam keberhasilaan menyampaikan dakwah secara lisan (ceramah). Penguasaan retorika bermanfaat untuk mengatur apa yang akan disampaikan, metode dakwah apa yang digunakan, serta pesanpesan apa yang perlu dikemukakan. Dalam hal berdakwah secara lisan, ceramah memiliki kesamaan dengan pidato. Keduanya merupakan ragam keterampilan berbicara yang bersifat satu arah dan dilakukan di depan khalayak umum.

Retorika dakwah Ustaz Yusuf Mansur terdiri atas struktur retorika dakwah, metode dakwah, strategi penyusunan pesan, serta gaya dakwah. Sumber data penelitian ini ialah keempat judul ceramah Ustaz Yusuf Mansur yakni, 10 Dosa Besar Vol.2, Libatkan Segala Urusan Bersama Allah, Allah Dulu, Allah Lagi, Allah Terus, dan Ditolong Allah. Dari segi struktur materi dakwah Ustaz Yusuf Mansur berdasarkan analisis keempat judul ceramah yang dilakukan, maka dapat disimpulkan bahwa Ustaz Yusuf Mansur umumnya menyampaikan dakwah dengan struktur ceramah yang lengkap yakni terdiri atas pembuka, isi, dan penutup. Namun, secara umum dapat diketahui bahwa Ustaz Yusuf Mansur dalam berdakwah tidak terlalu memperhatikan bagian pembuka. Bagian pembuka ceramah Ustaz 
Yusuf Mansur bersifat sangat sederhana berupa salam pembuka, pujian kepada Allah Swt, shalawat kepada Rasulullah Saw, dan mengemukakan pernyataan pengantar menuju pesan utama. Bagian isi ceramah Ustaz Yusuf Mansur dominan berupa contoh, kisah, dan dalil AlQur'an. Ustaz Yusuf Mansur banyak mengungkapkan contoh mengenai keadaan suatu hal, akhlak, serta contoh tokoh dan permasalahan hidup tokoh. Bagian penutup ceramah Ustaz Yusuf Mansur memiliki komposisi lebih banyak daripada bagian pembuka ceramah Ustaz Yusuf Mansur. Hal ini dikarenakan umumnya bagian penutup ceramah Ustaz Yusuf Mansur ditutup dengan simpulan, harapan, doa, dorongan untuk berbuat, dan salam penutup. Simpulan ceramah Ustaz Yusuf Mansur bersifat sederhana biasanya berupa pengulangan inti pesan secara singkat dan lebih didominasi dengan doa.

Metode dakwah yang digunakan Ustaz Yusuf Mansur terdiri atas metode Al- Hikmah dan metode Al- Mauizah Al- Hasanah. Metode yang paling dominan digunakan dalam berceramah ialah metode Al- Mauizah Al- Hasanah. kedua metode ini memiliki perbedaan konsep. Konsep metode Al-Hikmah yakni mengatakan hal yang benar dengan cara yang benar. Metode Al-Hikmah yang umumnya digunakan Ustaz Yusuf Mansur dalam ceramah berupa pemaparan dalil Al-Qur'an, penjabaran fakta, dan penyampaian pernyataan yang logis. Konsep metode Al- Mauiza Al- Hasanah yakni menyampaikan pesan ceramah dengan cara menyentuh hati pendengar. Metode Al- Mauizah Al- Hasanah yang digunakan Ustaz Yusuf Mansur dalam berceramah berupa penjabaran contoh, kisah, dan wasiat.

Analisis strategi penyusunan pesan ceramah Ustaz Yusuf Mansur pada keempat judul ceramah secara umum dapat disimpulkan bahwa Ustaz Yusuf Mansur menggunakan strategi penyusunan pesan berupa imbauan rasional, emosional, takut, ganjaran, dan motivasional. Imbauan pesan yang dominan digunakan Ustaz Yusuf Mansur yakni imbauan rasional, emosional dan takut. Imbauan rasional berupa pemaparan contoh, bukti, dalil Al-Qur'an dan kisah-kisah yang mempengaruhi tingkat kepercayaan pendengar. Imbauan emosional yang dominan digunakan Ustaz Yusuf Mansur yakni mengemukakan pernyataanpernyataan yang menggugah hati dan perasaan pendengar. Umumnya Ustaz Yusuf Mansur banyak mengemukakan pernyataan mengenai sikap manusia yang dalam hidupnya banyak melupakan dan tidak menghargai Allah Swt. Imbauan takut yang digunakan Ustaz Yusuf Mansur berupa penyampaian peringatan dan ancaman yang membuat takut mengenai sikap-sikap yang jauh dari tauhid akan mendapatkan adzab dari Allah Swt. Temuan penelitian memperlihatkan adanya hubungan antara imbauan rasional dan emosional yakni dalam penjabaran beberapa bukti berupa kisah dan contoh dalam ceramah tidak hanya menyentuh aspek logis atau rasional, tetapi kisah dan contoh tersebut juga menyentuh aspek emosional.

Gaya dakwah Ustaz Yusuf Mansur terdiri atas gaya dakwah, diksi, dan gaya bahasa. Gaya komunikasi Ustaz Yusuf Mansur memiliki ciri khas sebagai pendakwah yang tidak mengebu-gebu dan menyampaikan ceramah dengan tidak terikat pada kekhasan intonasi tertentu. Ustaz Yusuf Mansur senantiasa menyampaikan ceramah dengan gaya komunikasi yang bersahabat, akrab, dan santai. Kekhasan Ustaz Yusuf Mansur ialah pada penggunaan diksi yang dominan berupa kata-kata percakapan sehari-hari dengan nuansa Betawi. Bahasa yang digunakan mudah dipahami dan menimbulkan efek keakraban antara pembicara dan pendengar. Gaya bahasa yang digunakan Ustaz Yusuf Mansur berupa gaya bahasa penegasan, perbandingan, pertentangan, dan sindiran. Namun, gaya bahasa yang dominan digunakan ialah gaya bahasa penegasan dan gaya bahasa perbandingan.

Hasil analisis retorika dakwah Ustaz Yusuf Mansur dan angket tanggapan pendengar 
Ustaz Yusuf Mansur terdapat kesamaan dan sedikit perbedaan. Kesamaan yakni pada struktur ceramah, metode ceramah, dan gaya komunikasi. Perbedaan antara analisis retorika dengan angket tanggapan pendengar Ustaz Yusuf Mansur ialah pada strategi penyusunan pesan. Hasil analisis mendeskripsikan imbauan pesan paling dominan ialah imbauan pesan rasional, sedangkan pada angket tanggapan pendengar imbauan pesan yang paling dominan ialah imbauan motivasional dan urutan imbauan kedua ialah rasional. Hal ini wajar sebab video Ustaz Yusuf Mansur yang pernah dilihat atau disaksikan responden bisa saja berbeda dengan sumber data penelitian. Namun, secara keseluruhan hasil angket tanggapan pendengar Ustaz Yusuf Mansur sejalan (balance) dan memperkuat hasil analisis (temuan) dalam penelitian ini.

Pemanfaatan hasil penelitian mengenai retorika dakwah Ustaz Yusuf Mansur ini berupa bahan ajar berbicara dalam bentuk CD interaktif untuk siswa SMA. Bahan ajar ini bertujuan melatih dan mengembangkan keterampilan berbicara siswa yakni dalam berceramah. CD interaktif ini dirancang dengan menggunakan format media flash adobe CS 6 dan didesain dengan metode pembelajaran tanya jawab, pemodelan, serta latihan. Bahan ajar berbicara berbasis religius dalam bentuk CD interkatif ini dilengkapi dengan program webcam untuk merekam keterampilan berbicara siswa dalam hal praktik. Idealnya pembelajaran dilaksanakan dengan terlebih dahulu memberikan informasi, pengetahuan, dan konsep mengenai ceramah kepada siswa, kemudian menginstruksikan siswa mempersiapkan diri untuk berceramah dengan terlebih dahulu membuat teks ceramah dan berlatih berceramah dengan lafal, intonasi, jeda, dan ekspresi yang tepat. Namun, aplikasi bahan ajar ini dapat disesuaikan dengan pembelajaran di sekolah sehingga dapat dilaksanakan dalam dua kali pertemuan. 


\section{Daftar Pustaka}

Abidin, Y.Z. 2012. Pengantar retorika. Bandung: Pustaka Setia

Arbi, A. 2012. Psikologi komunikasi dan tabligh. Jakarta: Bumi Aksara.

Arsjad, M.G. dan Mukti (1988). Pembinaan kemampuan berbicara bahasa indonesia. Jakarta: Erlangga.

Enjang, A. 2009. Dasar-dasar ilmu dakwah. Bandung: Widya Padjadjaran.

Enjang, \& Hajir, T. (2009). Etika dakwah; suatu pendekatan teologis \& filosofis. Bandung: Widya Padjajaran.

Iskandarwassid \& Sunendar, D. (2009) Strategi pembelajaran bahasa. Bandung: Rosdakarya.

Keraf, G. 2006. Diksi dan gaya bahasa. Jakarta: Gramedia Pustaka Utama.

Maarif, Z. 2014. Retorika metode komunikasi publik. Jakarta: Dapur Buku.

Oka, I.G.N. 1976. Retorik sebuah tinjuan pengantar. Bandung: Terate.

Prastowo, A. 2014. Kreatif menulis bahan ajar inovatif. Yogyakarta: Diva Press..

Rahim, A. 2011. Retorika haraki. Surakarta: PT Era Adicitra Intermedia.

Rudi, S.C.R. 2008. Media pembelajaran. Bandung: CV Wacana Prima.

Rusman. 2004. Pengembangan model pembelajaran berbasis komputer. Bandung: UPI.

Rusman. 2012. Model-model pembelajaran mengembangkan profesionalisme guru. Jakarta: Rajawali Pers.

Sanjaya. W. 2008. Strategi pembelajaran. Jakarta: Kencana Prenada Media Group.

Sanjaya,W. 2010. Perencanaan dan desain sistem pembelajaran. Jakarta: Kencana.

Saputra, W. 2011. Pengantar ilmu dakwah. Jakarta: PT RajaGrafindo Persada.

Shihabuddin. 2009. Evaluasi pengajaran bahasa indonesia. Bandung: UPI.

Sudjana, N. \& Rifai, A. 2005 Media pengajaran. Bandung: Sinar Baru Algendindo.

Syafi'ie, I. 1988. Retorika dalam menulis. Jakarta: P dan K.

Tarigan, H.G. 2008. Berbicara sebagai suatu keterampilan berbahasa. Bandung: Angkasa.

Tasmara, T. 1990. Komunikasi Dakwah. Jakarta: Gaya Media Pratama.

Waridah, E. 2008. EYD \& seputar kebahasaan-indonesiaan. Jakarta: Kawan Pustaka.

Wiyanto, A. 2001. Terampil pidato. Jakarta: Gramedia Widiasarana Indonesia. 